\title{
Investigation the role of experiential avoidance on anticipation general health in non-clinical samples
}

\section{Nemat Allah Yarollahi ${ }^{1}$, Mohammad Reza Shairi ${ }^{2}$}

1- M.A. Sc. in clinical psychology, Shahed University, Tehran, Iran. ORCID: 0000-0003-0744-3405

E-mail:n.yaralahi@yahoo.com

2- Associate Professor of clinical psychology, Faculty of Humanities, Shahed University, Tehran, Iran. ORCID: 0000-0002-2037-3475

\section{Abstract}

Introduction: Experiential avoidance is one of the trans-diagnostic factors that can play an important role in formation and continuity many problems of individual's mental health.

Aim: The aim of the current study was to investigate the role of experiential avoidance on general health in non-clinical samples.

Method: In this cross-sectional study, the number of 150 students of Shahed University were selected via multi-stage cluster sampling method. Tools that used in this study were Acceptance and Action Questionnaire (AAQ-II), and General Health Questionnaire (GHQ12).

Results: Pearson correlation coefficient showed that there is a significant relationship between experiential avoidance with general health $(\mathrm{p}<0.01)$. Regression analysis also showed that experiential avoidance has a significant role on anticipation general health $(\mathrm{p}<$ 0.01). Regression analysis indicated that the experiential avoidance can predict $42 \%$ of variance of general health in university students.

Conclusion: Finding showed that experiential avoidance has a counterproductive effect on general health in college's students. Thus, it is necessary to considering suitable solutions to reduce experiential avoidance in order to prevent psychology problems.

Keywords: Experiential avoidance, General health, University students.

How to cite this article : Yarollahi N A, Shairi M R. Investigation the role of experiential avoidance on anticipation general health in nonclinical samples. Shenakht Journal of Psychology and Psychiatry. 2018; 5 (3): 1-11 .URL: http://shenakht.muk.ac.ir/article-1-485-fa.pdf

Copyright ( 2018 the Author (s). Published by Kurdistan University of Medical Sciences. This is an open access article distributed under the terms of the Creative Commons Attribution-Non Commercial License 4.0 (CCBY-NC), where it is permissible to download, share, remix, transform, and buildup the work provided it is properly cited. The work cannot be used commercially without permission from the journal. 


\section{بررسى نقش اجتناب تجربهاى در بيشبينى سلامت عمومى در جمعيت غير بالينى}

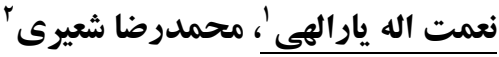

1. كارشناسى ارشد روانشناسى بالينى، دانشگاه شاهد، تهران، ايران. ايميل: n.

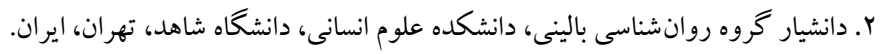

مقدمه: اجتناب تجربهاى يكى از عوامل فر اتشخيصى است كه مىتو اند نقش مهمى را در شكل گيرى و تداوم بسيارى از مشكلات مربوط به سلامت روانى افراد ايفا كند.

هدف: يُزوهش حاضر بهمنظور بررسى نقش اجتناب تجربهاى در بيشبينى سلامت عمومى در جمعيت غير بالينى انجام كرفت. روش: در اين مطالعه مقطعى، تعداد •lه دانشجوى كارشناسى و كارشناسى ارشد دانشگاه شاهد از طريق نمونه گيرى خوشهاى

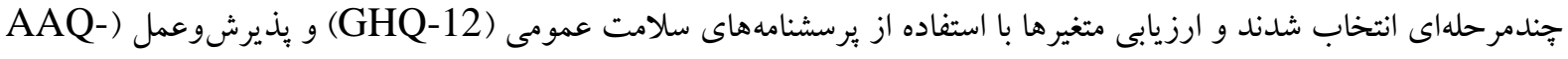
صورت بذيرفت. (II

يافتها: نتايج ضريب همبستخى بيرسون نشان داد كه بين اجتناب تجربهاى و سلامت عمومى رابطه منفى و معنادار ( (1/./P)

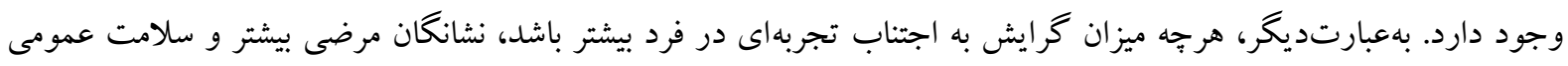

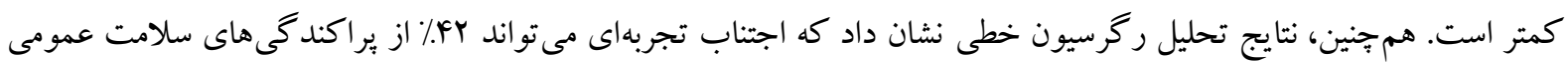

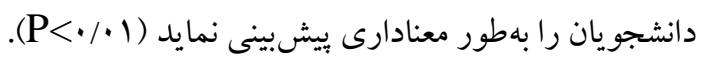
نتيجه كيرى: با توجه به نتايج اين يُزوهش و بهمنظور بيش گيرى از مشكلات روانشناختى دانشجويان، لازم است راه كارهاى

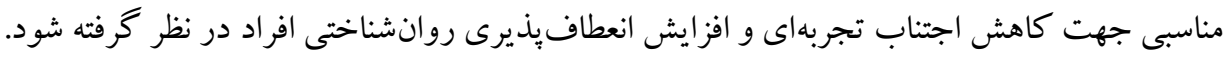
كليد وازهها: اجتناب تجربهاى، سلامت عمومى، دانشجويان. 
باشد- مى تواند سلامت روانشناختى آنها را به خطر مقدمه

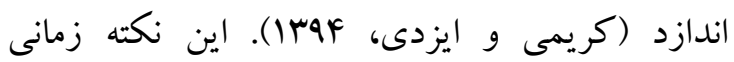

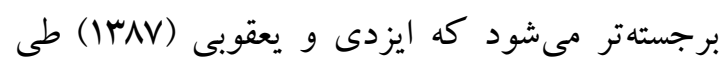

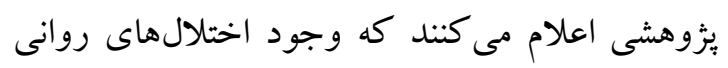
بهتنهايى مىتواند مهمترين مسئوليت حرفهاى دانشجويان، يعنى عملكرد تحصيلى آنان را تحت تأثير

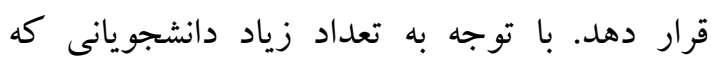

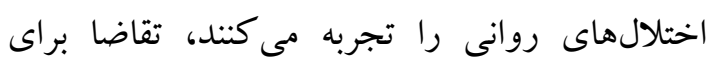

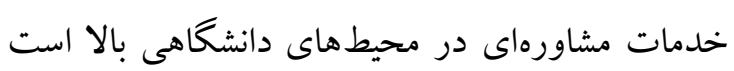

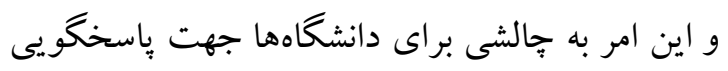

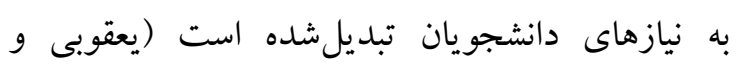

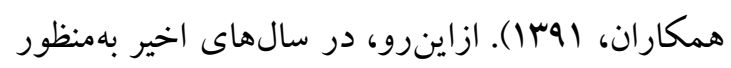
حفظ سلامت روان دانشجويان به برنامههاى بيش گيرى توجه ويزهاى شده است.

هرجند تحقيقات آسيبشناسى بهطور سنتى اختلال

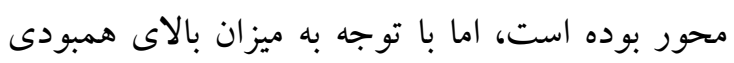

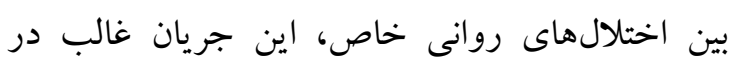

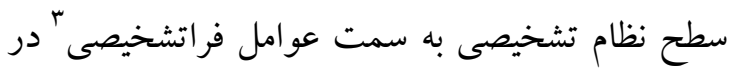

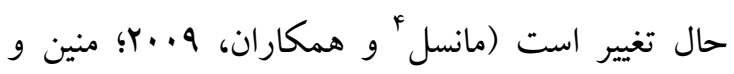

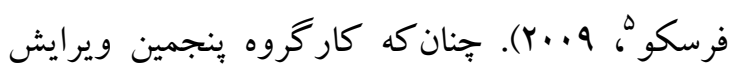

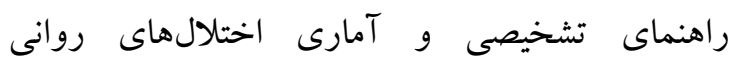
(DSM-5)

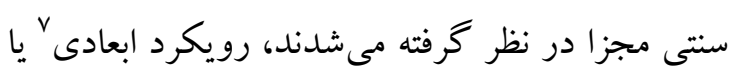

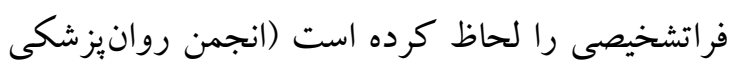

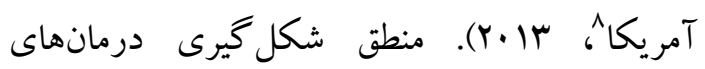
فراتشخيصى مبتنى بر مفاهيم نظرى و نتايج تجربى در

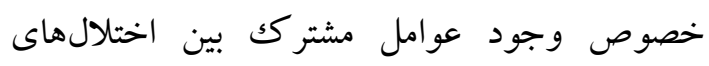
هيجانى بوده است كه عمدتاً با هدف مورد آماج قرار

\footnotetext{
${ }^{3}$ trans-diagnostic

${ }^{4}$ Mansell

${ }^{5}$ Mennin, \& Fresco

${ }^{6}$ Diagnosis and Statical Manual of Mental Disorders (DSM)

${ }^{7}$ dimensional

${ }^{8}$ American Psychiatric Association (APA)
}

سازمان جهانى بهداشت' (· • (Y. سلامت را دارا بودن عملكرد مناسب در جهار حوزه جسمانى، روانى، اجتماعى و معنوى تعريف مى كند كه داراى تأثير متقابل و يويا هستند. مفهوم سلامت دربر گيرنده مفاهيمى همجيون احساس خوب بودن و اطمينان از خود كار آمدى، اتكا به خود، ظرفيت رقابت، تعلق بين نسلى و خود شكوفايى توانايىهاى بالقوه فكرى، هيجانى و غيره است و فقدان بيمارى و علائم را نيز

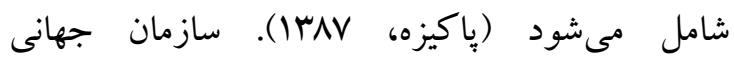
بهداشت، همجنين، سلامت روانى را بهعنوان "حالتى از سلامت بهزيستى كه در آن فرد توانايىهاى خود را بها

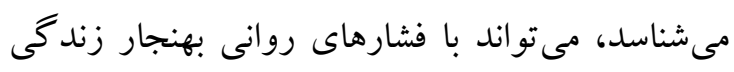

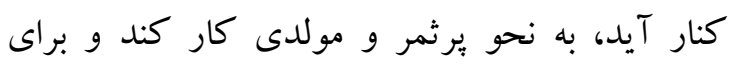

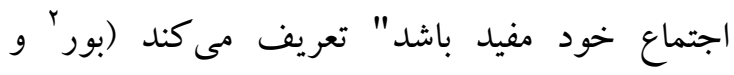
همكاران،1999؛ به نقل از عليان فينى و قاسمى، هوبار). سلامت روانى بهعنوان يكى از اركان سلامتى، لازمه يكك زندگى مفيد، مؤثر و رضايتبخش فردى است و و مسئوليت سنجش، ارزيابى، كنترل، درمان و بهبود بخشيدن آن قبل از هر كس بر عهده متخصصان علوم

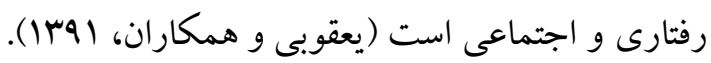
از سوى ديخر، دانشجويان قشر وسيعى از جمعيت فعال يكك كشور را تشكيل مىدهند و توجه به سلامت روانى آنها بهعنوان يكى از اقشار مؤثر و سازنده آينده

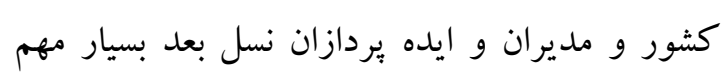

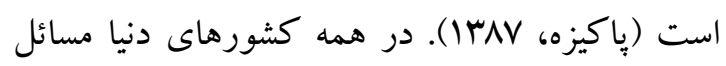
دانشگاهى و مشكلات فراوان دانشجويى دامنه وسيعى به خود كرفته و به نظر مىرسد عوامل مختلفى - كه مه مراسئ ممكن است ناشى از محرككهاى درونى، عوامل بيرونى و تنيدكى هاى محيطى و يا تركيبى از آنها

\footnotetext{
${ }^{1}$ World Health Organization (WHO)

${ }^{2}$ Boer
} 


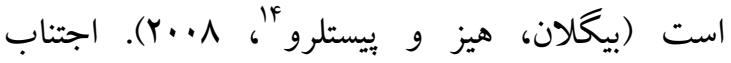
تجربهاى بهعنوان تلاشهايى انعطافنايذير براى اجتناب از تجربههاى هيجانى يا روانشناختى، سر كوب

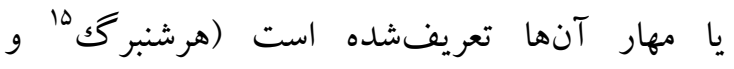

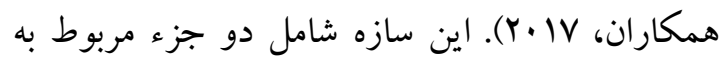
هم است: اول، بىميلى نسبت به برقرارى تماس با تجارب شخصى، احساسهاى بدنى، هيجانها، افكار، خاطرهها و زمينهاى رفتارى؛ و دوم، تلاش براى اجتناب از تجارب دردناكك و يا وقايعى كه باعث فراخو اندن اين تجارب مى كردند. اين شكل از اجتناب شامل اجتناب رفتارى، عاطفى و شناختى نيز مى شود

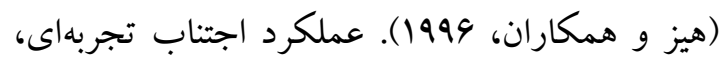
كنترل يا به حداقل رساندن تأثير تجارب آزارنده است

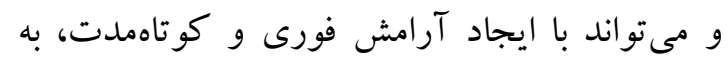
شكل منفى رفتار اجتنابى را تقويت نمايند. اين اجتناب زمانى مشكلزا خواهد شد كه با عملكرد روزانه و دستيابى به اهداف زندگى شخص تداخل نمايد

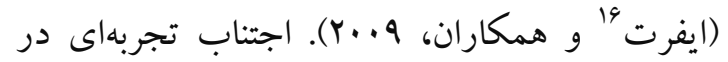
مقابل يذيرش - كه به معناى تمايل فرد به يذيرش كامل افكار، هيجانها و تظاهرات رفتارى، بدون تلاش براى اجتناب از آنها است- قرار مى گيرد و ازاينرو، با انعطافنايذيرى روانشناختى همراه است (ايزدى و و

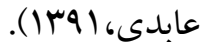
يزوهشهاى قابلتوجهى نشان مىدهد كه اجتناب

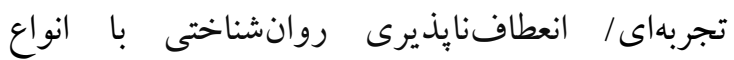

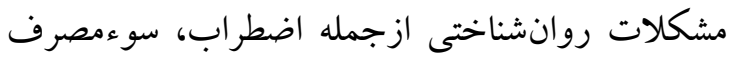

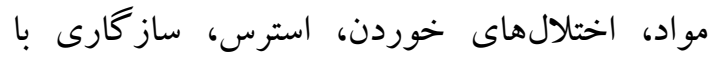
تجربيات آسيبزا، ساز كارى با شرايط مزمن بز شكى و و فرسودگى شغلى رابطه دارد (هيز و همكاران، 1999؛

${ }^{14}$ Biglan, Hayes, \& Pistorello

${ }^{15}$ Hershenberg

${ }^{16}$ Eifert
دادن اين عوامل سببساز در طيف وسيعى از اختلالهاى روانشناختى طراحى شدهاند (كراسكى، Y Y. Y). بهاينترتيب، باوجود اين كه امروزه برنامههاى

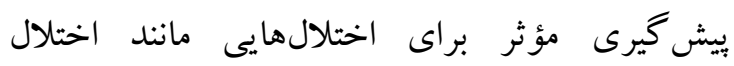
خوردن، سوءمصرف الكل، افسردگى و اضطراب

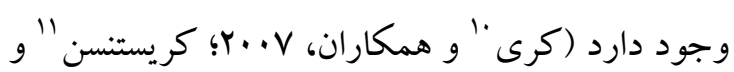
همكاران، •(Y.1)، اما استفاده از اين برنامهها در

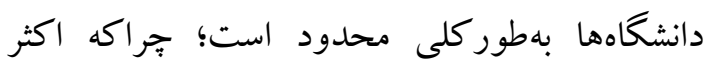

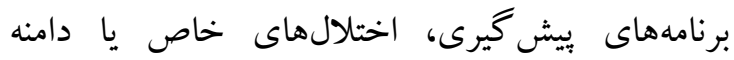

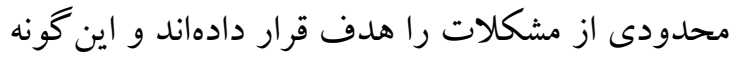
مداخلات نياز به جلسات متعدد با متخصصان

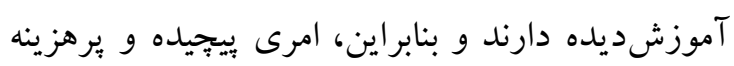
خواهد بود (عليان فينى و قاسمى، هوسا). يكى از روشهاى اميدواركننده براى غلبه بر موانع فوق، اجراى برنامههاى بيش گيرى كنندهاى است كه بتواند با هدف قرار دادن عوامل خطرساز مشترك بين اختلالهاى روانشناختى به بيش گيرى و بهبود طيف

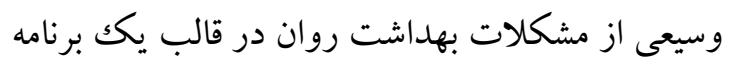

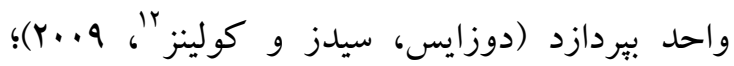
بنابراين، شناسايى اين عوامل مشترك از اهميت ويزهاى برخوردار است و مىتواند به متخصصان

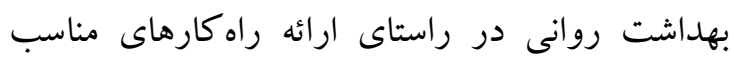
جهت ارتقاى سلامت روانى دانشجويان كمك شايانى بكند. (- n در سالهاى اخير به اجتناب تجربهاى" بهاعنوان يكك عامل فراتشخيصى حائز اهميت -كه مىتواند نقش مهمى را در شكل گيرى و تداوم بسيارى از مشكلات مربوط به سلامت روانى ايفا كند- توجه زيادى شده

\footnotetext{
${ }^{9}$ Craske

${ }^{10}$ Carey

${ }^{11}$ Christensen

${ }^{12}$ Dozois, Seeds, \& Collins

${ }^{13}$ experiential avoidance
} 
يثزوهشهاى كمترى در رابطه با اجتناب تجربهاى بهنوان يكك عامل فراتشخيصى تأثير گذار بر سلامت روانى افراد انجامشده است. بهاينترتيب، مسئله اساسى

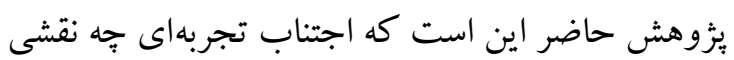
در سلامت عمومى دانشجويان در فرهنگك ايرانى دارد.

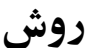

يثزوهش حاضر يكك يُوهش توصيفى از نوع مقطعى است. جامعه يزٔوهش شامل كليه دانشجويان كارشناسى و كارشناسى ارشد دانشگاه شاهد تهران در سال تحصيلى \$ه-ه بود كه از اين ميان، تعداد •ها نفر از

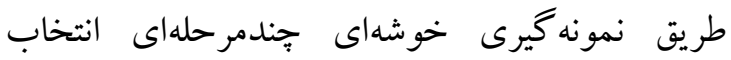
شدند. در مرحله نخست، از بين دانشكدههاى دانشگاه شاهد جند دانشكده بهتصادف انتخاب و سبِ از ميان هر كدام از آنها جند كلاس انتخاب گرديد. در آخر، نمونه يُزوهش از بين كلاسهاى يادشده بهتصادف انتخاب شد و ابزارهاى يُزوهش ميان آنها توزيع كرديد. معيارهاى ورود و خروج آزمودنىها در مطالعه

$$
\text { حاضر به شرح زير بود: - مان }
$$$$
\text { الف: معيارهاى ورود }
$$

1. دانشجويان شاغل به تحصيل در دوره كارشناسى و

$$
\begin{aligned}
& \text { كارشناسى ارشد دانشگاه شاهد } \\
& \text { Y. بازه سنى بين \1 تا بر سال } \\
& \text { ب: معيارهاى خروج }
\end{aligned}
$$

1. دانشجويان شاغل به تحصيل در دوره دكترى

دانشگاه شاهد

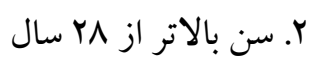

لازم به ذكر است بيش از شروع يُزوهش، آزمودنىها آمادكى و رضايت خود را جهت شركت در تحقيق

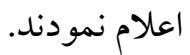

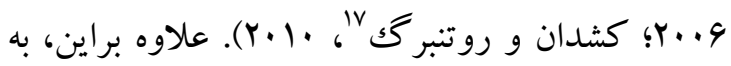

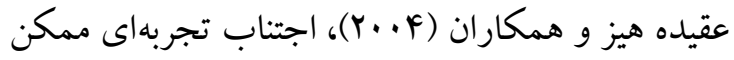
است با بسيارى از بيامدهاى منفى مانند مشكلات خلقى

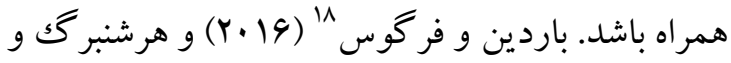

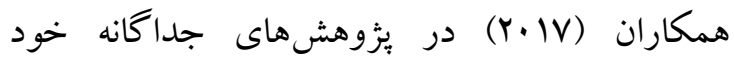
دريافتند افرادى كه نمره اجتناب تجربى بالايى دارند؛

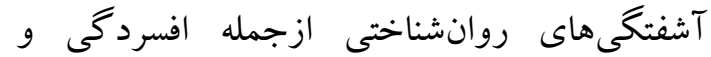
اضطراب بيشترى را تجربه مى كنند. آفتاب (هوسا) نيز در يزٔوهشى نشان داد كه دشوارىهاى بين فردى ناشى از راهبرد اجتناب از برخى افكار، خاطرهها و فعاليتها است كه در درازمدت به افسردگى و اضطراب منتهى رهي

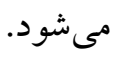
باوجود موارد ذكرشده، مطالعات انجامگرفته در اين زمينه همواره از نقش مخرب راهبردهاى اجتنابى و بورئ مبتنى بر كنترل مانند سركوب كردن حمايت نكردهاند و برخى يزٔوهشها اثربخشى راهبردهاى ازايندست را در سازش مؤثر با موقعيتها نشان دادهاند (يارالهى،

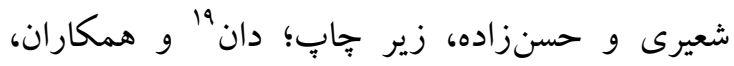

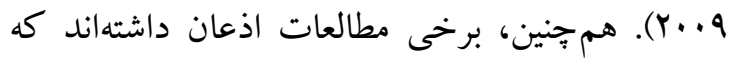

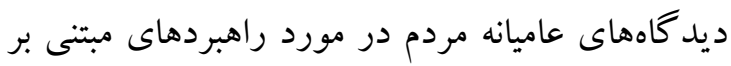
كنترل و استفاده از آنها در رويارويى با هيجانها از فرهنگ به فرهنگ ديخر تفاوتهايى وجود دارد.

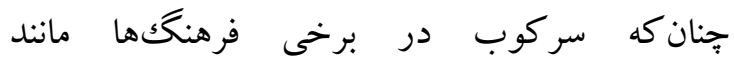

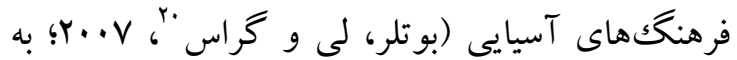

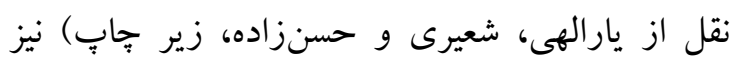
امرى رايجتر است. بهوركلى، باوجود شواهد زيادى از تأثير مخرب اجتناب تجربهاى بر مشكلات روانشناختى -و بعضاً وجود شواهد متناقض دراينباره، اما در ايران

${ }^{17}$ Kashdan, \& Rottenberg

${ }^{18}$ Bardeen, \& Fergus

${ }^{20}$ Butler, Lee, \& Gross 
فرمهاى كوتاهتر آن شامل GHQ-30، GHQ-28، GHQ-12 و GHQ-20 موارد گوناكون و فرهنگكهاى متفاوت گسترش يافته

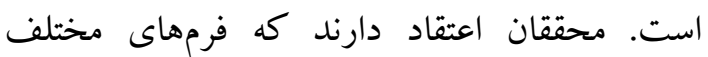
يرسشنامه سلامت عمومى از اعتبار و روايى بالا برخوردار است و كارايى فرم rا سؤالى تقريباً به همان

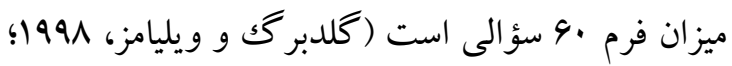
به نقل از يعقوبى و همكاران، الهr|). سؤالات يرسشنامه به بررسى وضعيت فرد در جهار هفته كذشته مى بردازد و به همين جهت سؤ الها بر موقعيت "اينجا و

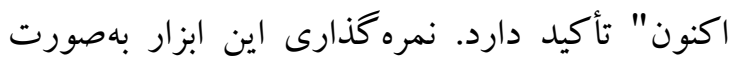
ليكرتى (r-Y-I-Iי) است كه نمرات بالا نمايانگر علائم مرضى بيشتر و نمرات بإيينتر نشان از ميزان سلامت بيشتر /ست. ئزوهشهاى بين فرهنكى نشان

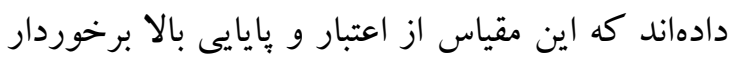
بوده و ابزار مناسبى جهت اندازهگيرى سلامت

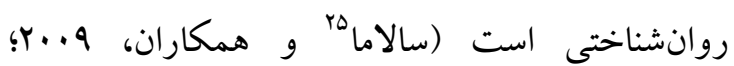

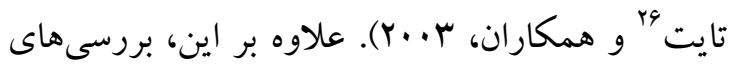
بهمل آمده از فرم با سؤالى GHQ در ايران در ايران ضريب آلفاى كرونباخ برسشنامه بو/ •؛ و ضريب اعتبار

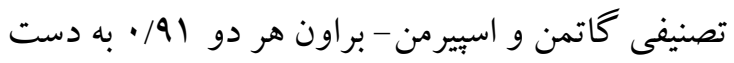

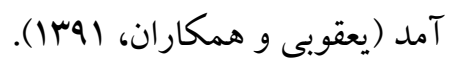
لازم به ذكر است، تجزيهوتحليل دادهها با آزمون آمارى ضريب همبستخى ييرسون و تحليل رگرسيون خطى با استفاده از نرمافزار SPSS نسخه سץ انجام شد.

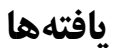

مطالعه حاضر بر روى •010 نفر از دانشجويان دانشگاه

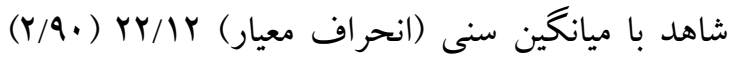

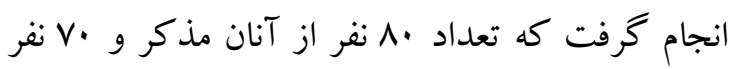

${ }^{25}$ Salama

${ }^{26}$ Tait
براى جمع آورى اطلاعات در اين يثوهش از برسشنامهاى زير استفاده شده است:

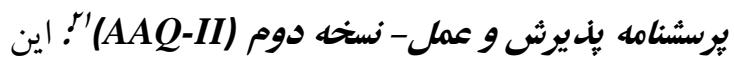

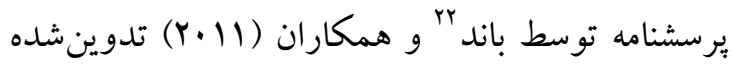
و يك نسخه ·. أسؤلى از برسشنامه اصلى (AAQ-I) است كه بهوسيله هيز و همكاران (Y......) ساخته شده بود. يرسشنامه يذيرش و عمل - نسخه دوم، همسو با نظريه زيربنايىاش، براى سنجش انعطافيذيرى روانشناختى، بهويزه در ارتباط با اجتناب تجربهاى و

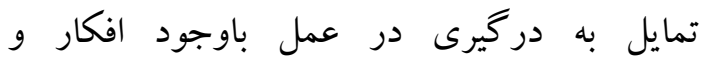
احساسهاى ناخواسته تدوينشده و بر اساس ميزان

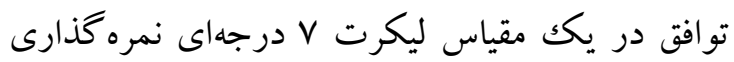
مىشود. نمرات بالاتر در اين مقياس نشاندهنده انعطاف يذيرى روانشناختى بايين تر و اجتناب تجربهاى بالاتر است. يافتهاى يثزوهشى پايايى، روايى و اعتبار سازه رضايت بخشى را براى اين ابزار زز ارش دادهاند:

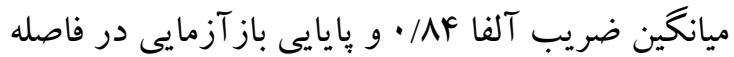

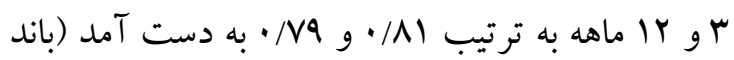

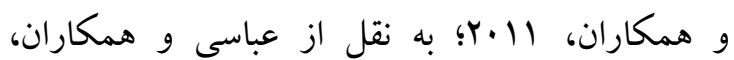

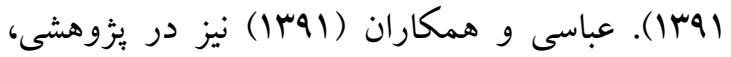
همسانى درونى و اعتبار همخراى قابل قبولى را براى نسخه فارسى نشان دادند. بهاين ترتيب، از اين برسشنامه جهت سنجش گرايش به اجتناب تجربهاى در افراد

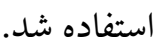

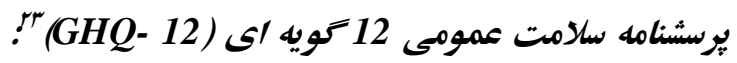

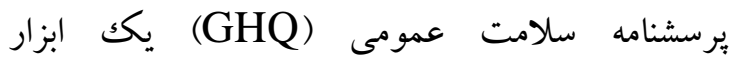

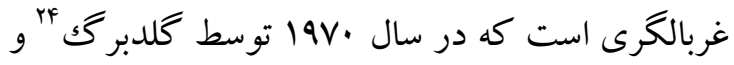
همكاران تدوين شد. اين برسشنامه اساساً بهعنوان يك درك

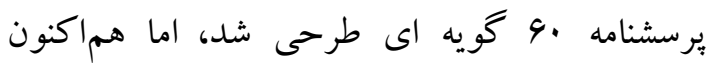

\footnotetext{
${ }^{21}$ Acceptance and Action Questionnaire (AAQ-II)

${ }^{22}$ Bond

${ }^{23}$ General Health Questioner

${ }^{24}$ Goldberg, \& Blackwell
} 
همبستخى بيرسون استفاده شد (جدول (). يافتها نشان داد كه بين اجتناب تجربهاى و نمرات فرد در برسشنامه يُه سلامت عمومى رابطه مثبت و معنادار وجود دارد

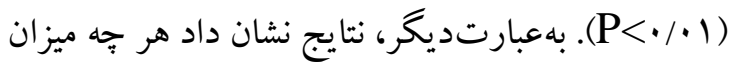
كرايش به اجتناب تجربهاى بيشتر باشد، نشانگان مرضى و درنتيجه نمره كل فرد در آزمون GHQ-12 نيز بيشتر است؛ و برعكس، هر جه انعطاف بذيرى روانشناختى بيشتر باشد، سلامت عمومى نيز بيشتر

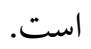

مؤنث بودند. •lf نفر از دانشجويان مجرد و •ا نفر متأهل بودند. همجنين، تعداد ..1 نفر از دانشجويان مشغول به تحصيل در دوره كارشناسى و بقيه آنها

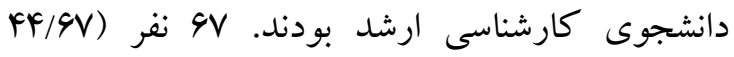
درصد) مربوط به دانشكده علوم انسانى،

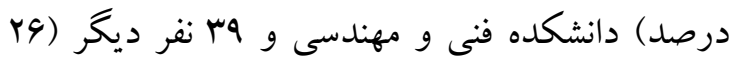
درصد) از دانشكده علوم يايه بودند.

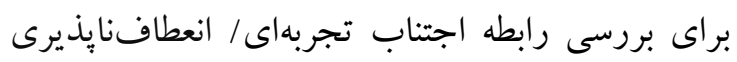
روانشناختى با سلامت عمومى از آزمون ضريب

\section{جدول ا. رابطه بين اجتناب تجربهاى با سلامت عمومى با استفاده از ضريب همبستكى ييرسون

\begin{tabular}{|c|c|}
\hline سلامت عمومى & اجتناب \\
\hline
\end{tabular}

\begin{tabular}{|c|c|c|}
\hline & 1 & اجتناب تجربهاى \\
\hline 1 & $0.65^{\text {糔 }}$ & سلامت عمومى \\
\hline
\end{tabular}

مربوط به جنسيت آزمودنىها تفاوت معنادارى را در كرايش به اجتناب تجربهاى و ميزان سلامت عمومى بين

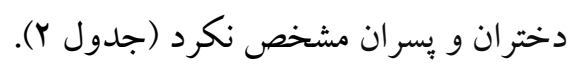

از سوى ديخر، يكى از اهداف فرعى اين يثوهش

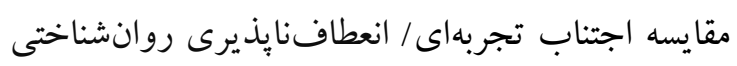
و سلامت عمومى دختران و وِسران بود. مقايسه نتايج

جدول 2. مقايسه اجتناب تجربهاى و سلامت عمومى در بين دختران و يسران

\begin{tabular}{|c|c|c|c|c|}
\hline سطح معنادارى & $\mathbf{t}$ & ميانكين (انحر اف معيار) & جنسيت & شاخص متغير \\
\hline 0.21 & 1.25 & (10.87) 51.44 & مرد & كر ايش به اجتناب \\
\hline 0.22 & 1.24 & (12.95) 49.00 & زن ان & تجربهاى \\
\hline 0.70 & -0.39 & (5.28) 14.03 & 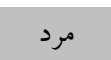 & سلامت عمومى \\
\hline 0.70 & -0.39 & (6.06) 14.39 & زن & \\
\hline
\end{tabular}

داده شده است، اجتناب تجربهاى مى تو اند بF درصد از براكندگى هاى سلامت عمومى دانشجويان را بهطور

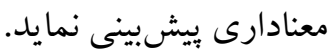

همجنين، بهمنظور تعيين نقش اجتناب تجربهاى در

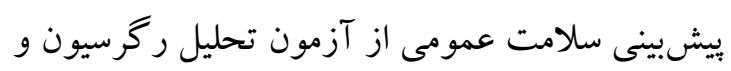
ضرايب بتا استفاده شد. همان گونه كه در جدول بـ انشان

جدول 3. نتايج تحليل ركرسيون خطى سلامت عمومى بر اساس اجتناب تجربهاى

\begin{tabular}{|c|c|c|c|c|c|c|c|}
\hline معنادارى سطح & $\mathbf{t}$ & 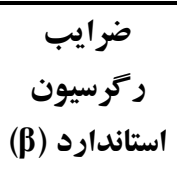 & $\begin{array}{c}\text { ضراير استاندارد } \\
\text { غايب } \\
\text { (B) }\end{array}$ & $\overline{\mathbf{R}^{2}}$ & $\mathbf{R}$ & شاخصهاى آمارى & ملاكك \\
\hline $0.001^{* * *}$ & 10.30 & 0.65 & 0.31 & 0.42 & 0.65 & اجتناب تجربهاى & سلامت \\
\hline
\end{tabular}




\section{عمومى}

اضطراب نقش معنىدارى در بيشبينى بيراكندگىهاى

سلامت روان و سلامت عمومى برستاران دارند. در تبيين اين يافتها مىتوان كفت افرادى كه از سطوح

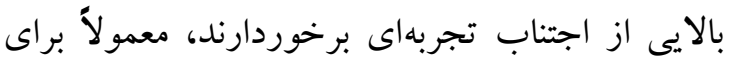
مديريت تجارب هيجانىشان از سركوب، اجتناب و ديخر راهبردهاى مبتنى بر كنترل استفاده مى كنند

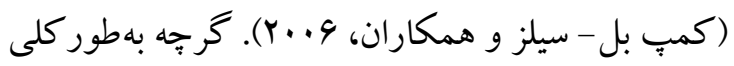
جنين راهبردهايى ممكن است بهعنوان ابزارى براى فرار از تجارب هيجانى بيزارى آور به كار گرفته شود،

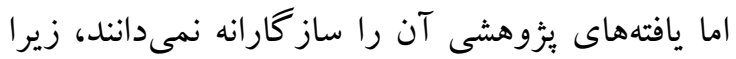

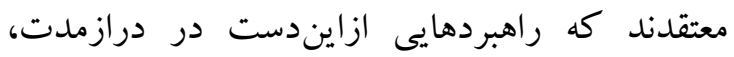
شاخصهاى فيزيولوزيك،، شناختى و روابط اجتماعى نو

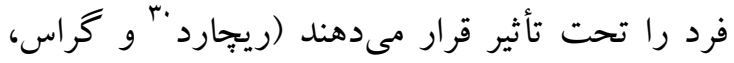

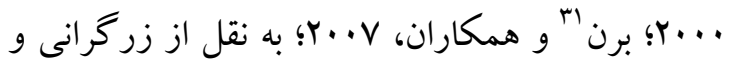

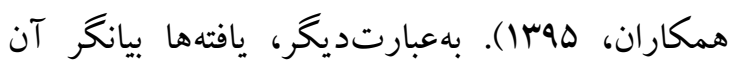

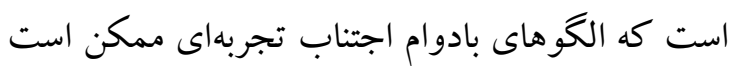
بيشتر با افزايش واكنشدهى به محرككهاى هيجانى همراه باشد تا كاهش آن (كمبٍ بل - سيلز و همكاران،

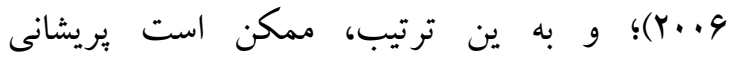
روانشناختى را افزايش دهد (كراس و لوينسون،

.$(199861994$ علاوه براين، در برخى رويكردهاى درمانى جديد، اجتناب تجربهاى بهعنوان سازهاى كليدى در ايجاد و تداوم مشكلات روانشناختى در نظر گرفته مىشود. براى مثال، درمان مبتنى بر بذيرش و تعهد (ACT)

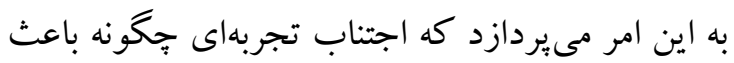
مىشود كه افراد قوانينى رادر مورد تجربه كردن افكار و هيجانهاى خاص براى خود ايجاد نمايند. اين قواعد

\footnotetext{
${ }^{30}$ Richards

${ }^{31}$ Burns

${ }^{32}$ Acceptance and Commitment Therapy (ACT)
}

هدف بيزوهش حاضر بررسى رابطه اجتناب تجربهاى با سلامت عمومى در دانشجويان دانشگاه شاهد بود. نتايج نشان داد كه بين اجتناب تجربهاى و نمرات سلامت عمومى رابطه مثبت و معنادار وجود دارد، به كونهاى كه هر جهه ميزان گرايش به اجتناب تجربهاى در فرد بيشتر

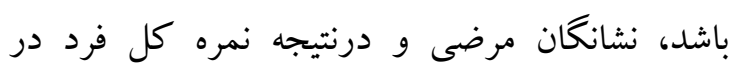
آزمون GHQ-12 نيز بيشتر است. علاوه بر اين، نتايج

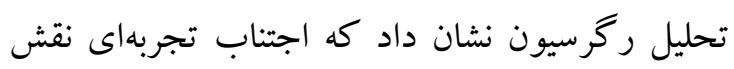
معنادارى در بيشبينى مشكلات مربوط به سلامت عمومى دارد. همسو با نتايج بزوهش حاضر، مطالعات تجربى نشان

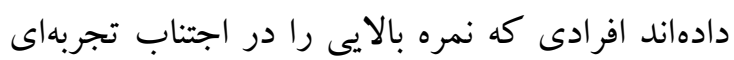
كسب مى كنند، با بريشانى هيجانى و هم هنين شناختهاى منفى بيشترى به مسائل هيجان زايى مثل

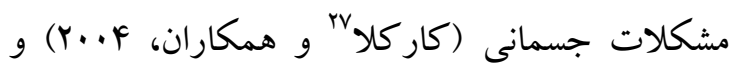

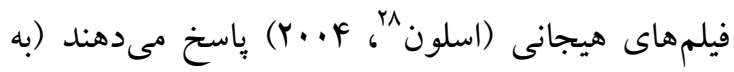

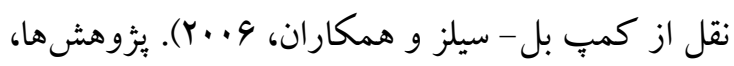
ارتباط اجتناب تجربهاى را با بسيارى از مشكلات مانند

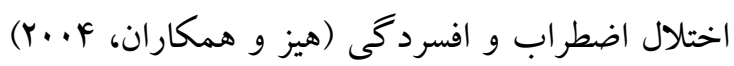
و برخى اختلالهاى ديخر ماند يُ خورى عصبى (كوير،

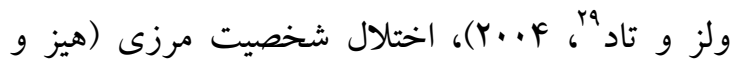
همكاران، 1999) نشان دادهاند. هم جنين، نتايج بزوهش كريمى و ايزدى (IMaf) نشان داد كه بين اجتناب

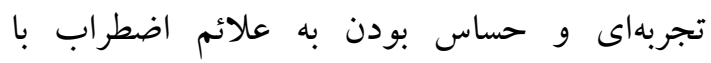
افسردگى، اضطراب، استرس و سلامت عمومى رابطه مثبت معنىدارى وجود دارد. بعلاوه، مشخص شد متغيرهاى اجتناب تجربهاى و حساس بودن به علائم

\footnotetext{
${ }^{27}$ Karekla

${ }^{28}$ Sloan

${ }^{29}$ Cooper, Wells, \& Todd
} 


\section{نتيجه كيرى}

يافتهاى يُزوهش نمايان ساخت اجتناب تجربهاى با سلامت عمومى دانشجويان ارتباط معنادارى دارد، به اين صورت كه هر جهه ميزان اجتناب تجربهاى در فرد بيشتر باشد، نشانكان مرضى نيز بيشتر است. همجنين، اجتناب تجربهاى مىتواند نقش معنادارى در يِيشينى مشكلات مربوط به سلامت عمومى افراد داشته باشد؛ بنابراين، بهمنظور ويش گيرى/ و درمان مشكلات روانشناختى افراد و بهويزه قشر دانشجو بهعنوان جمعيت جوان و فعال و آيندهازان كشور، لازم است راه كارهاى مناسبى جهت كاهش كرايش به اجتناب

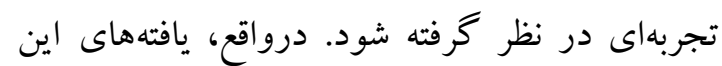
يُزوهش مى تواند رهنمودهايى را براى درمان مشكلات روانشناختى دانشجويان در نظر گيرد. براى مثال، مىتوان از درمان مبتنى بر يذيرش و تعهد و درمانهاى

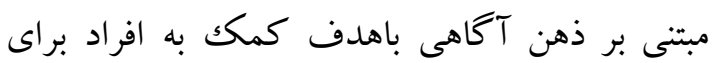
افزايش انعطاف يذيرى روانى نسبت به تجربيات درونى

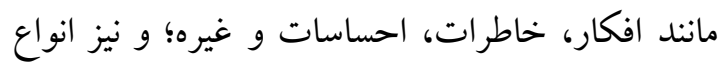
روشهاى رفتاردرمانى (مانند رفتاردرمانى ديالكتيكى)

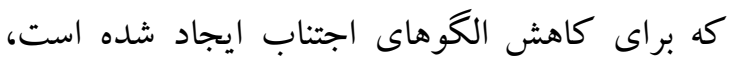

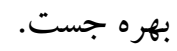

\section{سياسگزارى}

يزٔوهشخران بر خود لازم مىدانند از همه دانشجويانى كه در اين يثزوش شركت كردهاند؛ و همجنين از

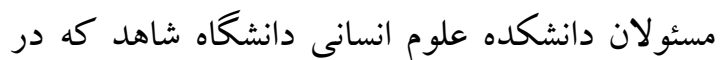
اجراى اين ئزوهش ياريخرشان بودهاند، صميمانه تشكر و قدردانى نمايند.

\section{References}

Abbasi, I., Ladan, F., Moloudi, R., \& Zarabi.H. (2013). Psychometric adequacy the Persian vision of the Acceptance and Action Questionnaire
مبناى باورها درباره تلويحات منفى تجربه اين هيجانها

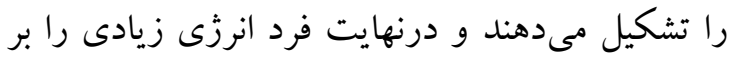
روى هيجانها و اجتناب از آنها سرمايه گذارى مى كند

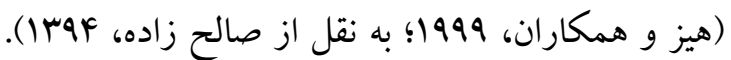
در اين درمان، هدف اصلى ايجاد انعطافيذيرى روانشناختى است؛ كه به توانايى افراد براى تمركز بر

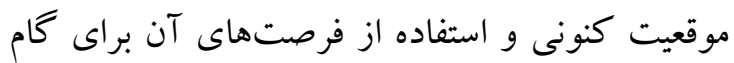
برداشتن در راستاى اهداف و ارزشهاى درونى، باوجود حضور رويدادهاى روانشناختى جالشبرانگيز

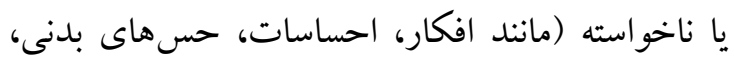
تصاوير ذهنى و خاطرهها) اشاره دارد (هيز و همكاران،

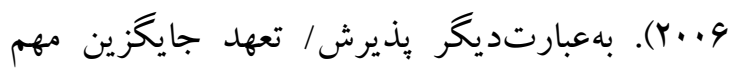
براى اجتناب تجربهاى است كه شامل تجربه كامل و

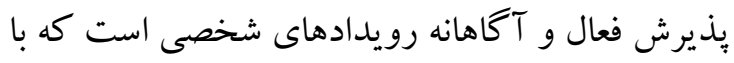
تاريخجه فرد مرتبط مىشوند و با عدم تلاش براى كاهش فراوانى يا تغيير شكل آن رويدادها همر اه است فرد (هيز و همكاران 1999؛ نريمانى، تكلوى واحدى،

.$(149)$

همانكونه كه اشاره شد، مقايسه نتايج مربوط به جنسيت آزمودنىها نيز تفاوت معنادارى را در متغيرهاى يادشده بين دختران و يسران مشخص نكرد.

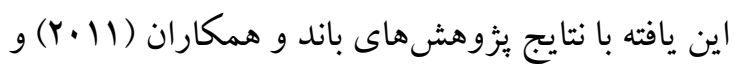
ايمانى (هوr()) هم سو است. درواقع، بر اساس نظريه ACT آسيبشناختى براى اختلالهاى روانى در تمام افراد است و وابسته به جنسيت نيست (هيز و همكاران،

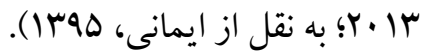
(AAQ-II). Psychological methods and models, 2 (10), 65-80. (Persian)

Aftab, R. (2016). The mediator role of interpersonal difficulties in relationship between experiential avoidance with depression and anxiety. Journal of 
Applied Psychology, Vol. 10, No. 4(40), 523-542. (Persian)

Bardeen, J. R., \& Fergus, T. A. (2016). The interactive effect of cognitive fusion and experiential avoidance on anxiety, depression, stress and posttraumatic stress symptoms. Journal of contextual behavioral science, 5(1): 1-6.

Biglan, A., Hayes, S. C., \& Pistorello, J. (2008). Acceptance and commitment: Implications for prevention science. Prevention science, 9(3), 139152.

Bond, F. W., Hayes, S. C., Baer, R. A., Carpenter, K, M., Guenole, N., Orcutt, H. K., Waltz, T.,\&Zettle, R., D. (2011). Preliminary Psychometric Properties of the Acceptance and Action Questionnaire-II: A Revised Measure OF Psychological Inflexibility and Experiential Avoidance. Behavior Therapy.

Burns, J. W., Quartana, P. J., \& Bruehl, S. (2007). Anger management style moderates effects of emotion suppression during initial stress on pain and cardiovascular responses during subsequent pain-induction. Annals of Behavioral Medicine, 34(2), 154-165.

Butler, E. A., Lee, T. L., \& Gross, J. J. (2007). Emotion regulation and culture: are the social consequences of emotion suppression culturespecific?. Emotion, 7(1), 30.

Campbell-Sills, L., Barlow, D. H., Brown, T. A., \& Hofmann, S. G. (2006). Effects of suppression and acceptance on emotional responses of individuals with anxiety and mood disorders. Behaviour research and therapy, 44(9), 1251-1263.

Carey, K. B., Scott-Sheldon, L. A., Carey, M. P., \& DeMartini, K. S. (2007). Individual-level interventions to reduce college student drinking: A meta-analytic review. Addictive behaviors, 32(11), 2469-2494.

Christensen, H., Pallister, E., Smale, S., Hickie, I. B., \& Calear, A. L. (2010). Community-based prevention programs for anxiety and depression in youth: a systematic review. The journal of primary prevention, 31(3), 139-170.

Cooper, M. J., Wells, A., \& Todd, G. (2004). A cognitive model of bulimia nervosa.British Journal of Clinical Psychology, 43(1), 1-16.

Craske, M. G. (2012). Trans-diagnostic treatment for anxiety and depression.Depression and anxiety, 29(9), 749-753.
De Boer, A. G., Wijker, W., Speelman, J. D., \& De Haes, J. C. (1996). Quality of life in patients with Parkinson9s disease: development of a questionnaire. Journal of Neurology, Neurosurgery \& Psychiatry, 61(1), 70-74.

Dozois, D. J., Seeds, P. M., \& Collins, K. A. (2009). Trans-diagnostic approaches to the prevention of depression and anxiety. Journal of Cognitive Psychotherapy, 23(1), 44-59.

Dunn, B. D., Billotti, D., Murphy, V., \& Dalgleish, T. (2009). The consequences of effortful emotion regulation when processing distressing material: A comparison of suppression and acceptance.Behaviour research and therapy, 47(9), 761-773.

Eifert, G. H., Forsyth, J. P., Arch, J., Espejo, E., Keller, M., \& Langer, D. (2009). Acceptance and commitment therapy for anxiety disorders: Three case studies exemplifying a unified treatment protocol. Cognitive and Behavioral Practice, 16(4), 368-385.

Goldberg, D. P., \& Blackwell, B. (1970). Psychiatric illness in general practice: a detailed study using a new method of case identification. $\mathrm{Br}$ med J, 2(5707), 439-443.

Goldberg, D., \& Williams, P. (1988). A user's guide to the General Health Questionnaire. NferNelson.

Gross, J. J., \& Levenson, R. W. (1993). Emotional suppression: physiology, self-report, and expressive behavior. Joumal of Personality and social Psychology, 64(6), 970.

Gross, J. J., \& Levenson, R. W. (1997). Hiding feelings: The acute effects of inhibiting negative and positive emotion. Joumal of abnormal psychology, 106(1), 95 .

Hayes, S. C., Follette, V. M., \& Linehan, M. M. (Eds.). (2004). Mindfulness and acceptance: Expanding the cognitive-behavioral tradition. New York, NY: GuilfordPress.

Hayes, S. C., Levin, M. E., Plumb-Vilardaga, J., Villatte, J. L., \& Pistorello, J. (2013). Acceptance and commitment therapy and contextual behavioral science: Examining the progress of a distinctive model of behavioral and cognitive therapy. Behavior therapy, 44(2), 180-198.

Hayes, S. C., Luoma, J. B., Bond, F. W., Masuda, A., \& Lillis, J. (2006). Acceptance and commitment therapy: Model, processes and outcomes. Behaviour research and therapy, 44(1), 1-25. 
Hayes, S. C., Strosahl, K., \& Wilson, K. G. (1999). Acceptance and commitment therapy: An experiential approach to behavior change. New York, NY: GuilfordPress.

Hayes, S. C., Wilson, K. G., Gifford, E. V., Follette, V. M., \& Strosahl, K. (1996). Emotional avoidance and behavioral disorders: A functional dimensional approach to diagnosis and treatment. Joumal of Consulting and Clinical Psychology, 64, 1152_1168.

Hershenberg, R., Mavandadi, S., Wright, E., \& Thase, M. E. (2017). Anhedonia in the daily lives of depressed veterans: A pilot report on experiential avoidance as a moderator of emotional reactivity. Journal of Affective Disorders, 208(1): 414-417.

Imani, M. (2016). Investigating the factor structure of the Acceptance and Action Questionnaire (AAQII) in university students. Journal of Teaching and Learning Studies. 8(1), 162-181.(Persian)

zadi, R., \& Abedi, M. R.(2015). Acceptance and Commitment Therapy, third edition. Tehran: Jungle publication. (Persian)

Karekla, M., Forsyth, J. P., \& Kelly, M. M. (2004). Emotional avoidance and panicogenic responding to a biological challenge procedure. Behavior Therapy, 35(4), 725-746.

Karimi, J., \& Izadi, R. (2015). The role of experiential avoidance and anxiety sensitivity in the prediction of mental and general health in Nursing Students. Iranian Joumal of Nursing Research, Vol. 10 No.4,32-42. (Persian)

Kashdan, T. B., \& Rottenberg, J. (2010). Psychological flexibility as a fundamental aspect of health. Clinical psychology review, 30(7), 865878.

Mansell, W., Carey, T. A., \& Tai, S. J. (2009). A Transdiagnostic Approach to CBT. J. Cognit. Psychother, 23, 6-19.

Mansell, W., Harvey, A., Watkins, E., \& Shafran, R. (2009). Conceptual foundations of the transdiagnostic approach to CBT. Joumal of Cognitive Psychotherapy: An International Quarterly, 23, 6-19.

Mennin, D. S., \& Fresco, D. M. (2009). Emotion regulation as an integrative framework for sian) understanding and treating psychopathology. Emotion regulation and psychopathology: $A$ transdiagnostic approach to etiology and treatment, 356-379.

Narimani, M., Taklavi, S., \& Ahadi, B. (2013). The modem methods of psychotherapy. Ardabil: Mohaghegh Ardabili publication. (Persian)

Richards, J. M., \& Gross, J. J. (2000). Emotion regulation and memory: the cognitive costs of keeping one's cool. Journal of personality and social psychology, 79(3), 410.

Salehzadeh. E. Z (2016). The study of Effect of thought suppression, emotional suppression and acceptance strategies on the type of memory retrieval. Master's Thesis of clinical psychology, Shahed University, Tehran, Iran. (Persian)

Sloan, D. M. (2004). Emotion regulation in action: Emotional reactivity in experiential avoidance.Behaviour Research and Therapy, 42(11), 1257-1270.

World Health Organization (2010). Mental health: concepts, emerging evidence practice. University of Melbourne, Geneva.

Yaghubi, H., Karimi, M., Omidi, A., Barouti, E., \& Abedi, M. (2012. Validity and factor structure of the General Health Questionnaire (GHQ-12) in university students. Journal of Behavioral Sciences, 6(2), 153-160. (Persian)

Yarollahi, N. A., Shairi, M. R., \& Hasanzadeh, Z. (in press). Investigating the effect of a brief period of praying in emotional suppression situation on mood and ego depletion. Joumal of Research on Religion \& Health. (Persian)

Zargarani N, Mashhadi A, Tabibi Z. (2016). Comparing the effectiveness of emotion regulation group training based on process model of gross on use of reappraisal and suppression strategies among adolescent girls with symptom of BPD and ADHD. Pejouhandeh;21(1):21-29. (Persian)

Zemestani, M., \& Imani, M. (2016). Effectiveness of transdiagnostic treatment on depression/anxiety symptoms and emotion regulation. Contemporary Psychology, 11 (1), 21-32. (Per 